\title{
Investigation of effect of viscosity on crystallization ability of spodumene glass-ceramic materials
}

\author{
O.Savvova, O.Babich, G.Shadrina, M.Kuriakin, A.Grivtsova \\ National Technical University "Kharkiv Polytechnic of Institute", \\ 21 Frunze Str., 61002 Kharkiv, Ukraine
}

Received January 27, 2016

\begin{abstract}
The influence of viscosity on crystallization ability, which determines strength properties of protective spodumene glass-ceramic materials, has been studied. It has been established that formation of volume-crystallized structure in lithium-aluminosilicate glasses in conditions of two-stage thermal treatment in the viscosity range of 109 Paps allows provision of mechanical properties required to obtain resistance against the action of energy-destructive factors. Obtained results may be used in developing glass-ceramic materials for modern composite armor.

Keywords: glass-ceramic materials, viscosity, crystallization ability, spodumene, strength, composite armor.

Исследовано влияние вязкости на кристаллизационную способность, которая обуславливает прочностные свойства защитных сподуменових стеклокристаллических материалов. Установлено, что формирование объёмно закристаллизованной структуры в литийалюмосиликатных стеклах в условиях двухстадийной термической обработки в области значений вязкости $10^{9}$ Па.с позволяет получить механические свойства, необходимые для обеспечения устойчивости $\mathrm{k}$ действию энергоразрушающих факторов. Полученные результаты могут быть использованы при проектировании стеклокристаллические материалов для современной композиционной брони.
\end{abstract}

Дослідження впливу в'язкості на кристалізаційну здатність захисних сподуменових склокристалічних матеріалів. О.В.Саввова, О.В.Бабіч, Г.М.Шадріна, М.О.Курякін, А.О.Гривцова .

Досліджено вплив в'язкості на кристалізаційну здатність, яка обумовлює міцносні властивості захисних сподуменових склокристалічних матеріалів. Встановлено, що формування об'ємно закристалізованої структури у літійалюмосилікатних стеклах в умовах двостадійної термічної обробки в області значень в'язкості $10^{9}$ Па.с дозволяє отримати механічні властивості, необхідні для забезпечення стійкості до дії енергоруйнуючих факторів. Одержані результати можуть бути використані при проектуванні склокристалічних матеріалів для сучасної композиційної броні.

\section{Introduction}

Evolution of science and technology involves development and implementation of the new types of polyfunctional materials that provide solutions for important objectives of materials science tasks. Currently, development of composite materials, includ- ing those combining high strength characteristics, thermal and electric properties and resistant to the variable factors is exceptionally important. Especially perspective composite materials are spodumene glass-ceramics, due to their high performance characteristics combined with technological effectiveness. Despite significant 
achievements in the field of creation and application of these materials for domestic appliances and thermally resistant equipment, improvement and development of the novel high-strength materials and technologies of their production is still an important tasks. This especially relates to medicine, provision of radiation safety, military branches etc. [1].

One of the perspective directions of development of spodumene glass-ceramic materials is their use as elements of personal armor protection [2]. Distinguishing feature of these glassceramic materials is the combination of high mechanical strength providing resistance against energy-destructive factors and ability to absorb and dissipate impact stresses, low density and relatively low cost. Obtaining the high-strength lightweight glass-ceramics with necessary values of performance properties is realized via inducing phase separation process with consequent fine crystallization of amorphous matrix with formation of the strengthened crystalline structure during low-temperature thermal treatment.

It should be noted that the high mechanical properties are provided by the secondary phase separation in the structure of glass materials being a stage of heterogeneous nucleation process. In this case crystal phases are formed having the structure that is mostly affined to the structure of the glass in terms of short-range order. This leads to decreased nucleation energy barriers, which can easily be overcome at relatively low temperatures of the initial glass crystallization [3]. Formation of the fine crystals with the size of $0.1 \div 1 \mu \mathrm{m}$ which are strongly bound with each other, as well as occurrence of thin sub-layers of glass between them, will bring the strength of the glass-ceramic materials close to theoretical, which, jointly with preventing the growth of cracks along the edges of the crystals, is a prerequisite of the high strength and stability of mechanical properties under adverse influences.

It should be noted that influence of viscosity on crystallization ability of semimelts of solid-liquid systems, which the glasses are related to, upon cooling from the melting temperature has a complex character, since along with the structural viscosity caused by formation of 3-dimensional framework, there the crystallization viscosity exists due to increase of quantity of the crystals [4].

It is known [5], that fluctuation structure has kinetic nature, and so it can be greatly developed in the systems with the low energy barriers on the path of structure and chemical transformations, with small relaxation time, particularly in the systems with low viscosity. High viscosity, however, plays an important role in kinetics of the process: the glass cannot separate into two layers in the observable time, vitreous phase is formed in the shape of fine droplets, which leads to rapid formation of developed dropwise double-skeleton structure.

According to the data by B.G.Varshal [5], the main distinctive characteristic of the metastable phase separation is that it occurs in conditions of elevated viscosity of both original melts and the melts being formed, i.e. the process is relatively slow. This influences the formation of significant amount of nuclei at the temperature of softening onset TE and formation of the glassceramic structure at the end temperature of crystallization. In these conditions, formation of double-phase materials with phase entities of minor size is possible, which is a prerequisite of the high mechanical strength of the final product [6]. For the low viscosity melts at high rate of crystal growth in the thermal treatment, formation of the larger crystals is possible, which can lead to lowering of the mechanical characteristics of the final product. Generally, the influence of chemical composition of the glass on its crystallization may be characterized with the following statement: tendency to crystallization in case of replacing one oxide with another one is lowered with increasing viscosity of the glass in the crystallization temperature range.

Glasses with composition that is optimal for obtaining the glass ceramics must have low rate of crystal growth $\left(K_{g}\right)$ in the range of formation temperature and high rate of the crystal growth in the range of crystallization temperature. Along with the rate of $f=K_{g}(T)$ curve, no less important is the location of where its maximum is shifted to. Such rate of dependence of $K_{g}$ versus temperature should be considered optimal, at which its maximum is shifted to the temperature region of less than softening point temperature, or to the area of viscosity values higher than $10^{8} \mathrm{~Pa} \cdot \mathrm{s}$ [7].

Analyzing aforementioned concepts it should be noted that investigation of the mechanism of complex interdependence between viscosity and crystallization ability in conditions of thermal treatment is an important stage in designing the protective spodumene glass-ceramic materials, which defines relevance of this work. 


\section{Experimental}

\subsection{Definition of the aim and research} methods

The aim of this work is to investigate the interdependence of viscosity and structure of the spodumene glasses in conditions of thermal treatment.

Occurrence and composition of the crystalline phase in the glasses was established using X-ray diffraction (XRD), petrographic and gradient-thermal methods of analysis. X-ray diffraction analysis was carried out using DRON-3M apparatus. Petrographic analysis was performed using polarization microscope NU-2E with magnification of up to $1000 \mathrm{X}$. Investigation of the phase transformations in the glasses and establishing their thermal treatment temperature were performed by differential thermogravimetric curves method on PaulikPaulik-Erday system Q-1500D derivatograph. Crystallization ability of the glasses was determined by gradient heating method in the temperature range of $20 \div 900^{\circ} \mathrm{C}$. Viscosity of the glasses was determined by thread elongation method on the viscosimeter manufactured by OJSC "Glass Institute" (Russian Federation).

2.2. Choice of criteria system for obtaining protective glass-ceramic materials for armor protection and requirements to base glass matrix

Obtaining the high-strength lightweight glass-ceramics with necessary values of performance characteristics is accomplished by provision of the phase separation process with consequent fine nucleated crystallization of the amorphous matrix with formation of reinforced crystalline structure at the low-temperature thermal treatment. Combination of the high mechanical strength for provision of resistance to energy-destructive components and ability to absorb and dissipate the impact stresses; low viscosity; and relatively low cost is characteristic to the spodumene glass-ceramic materials.

Based on these statements we chose the requirements to base glass matrix in obtaining the spodumene glass-ceramic materials:

- formation of $\left[\mathrm{AlO}_{4}\right]_{n}$ sybotaxic groups in the glass melt with consequent formation of crystallization nucleators during cooling due to metastable spinodal liquation;

- provision of glass viscosity of $\eta=$ $10^{8-9} \mathrm{~Pa} \cdot \mathrm{s}$ at softening temperature $T_{E}$;

- fine volume crystallization with formation of the high strength $\beta$-spodumene phase in amount of $80 \mathrm{vol}$. \% with crystal

Table 1. Chemical composition of model glasses and crystalline phases formed after melting a glasses

\begin{tabular}{|c|c|c|c|c|c|c|c|c|}
\hline \multirow[t]{3}{*}{ Group } & \multirow[t]{3}{*}{$\begin{array}{l}\text { Marking } \\
\text { of GSM }\end{array}$} & \multicolumn{4}{|c|}{$\begin{array}{c}\text { Chemical composition of model glasses, } \\
\text { mass } \%\end{array}$} & \multirow{3}{*}{$\begin{array}{c}\text { Melting } \\
\text { temperature } \\
,{ }^{\circ} \mathrm{C}\end{array}$} & \multirow{3}{*}{$\begin{array}{l}\text { Structure of } \\
\text { glasses after } \\
\text { melting }\end{array}$} & \multirow{3}{*}{$\begin{array}{c}\text { Structure of } \\
\text { glasses after } \\
\text { single-stage } \\
\text { thermal treatment }\end{array}$} \\
\hline & & \multicolumn{3}{|c|}{$\begin{array}{c}\text { Phase-forming } \\
\text { components }\end{array}$} & \multirow[t]{2}{*}{$\begin{array}{c}\text { Crystallization } \\
\text { catalyst }\end{array}$} & & & \\
\hline & & $\begin{array}{l}\mathrm{Li}_{2} \mathrm{O} \\
\left(\mathrm{LiF}_{2}^{*}\right)\end{array}$ & $\mathrm{Al}_{2} \mathrm{O}_{3}$ & $\mathrm{SiO}_{2}$ & & & & \\
\hline \multirow[t]{2}{*}{1} & SP-1 & 11.0 & 10.5 & 65.8 & $\underset{\mathrm{P}_{2} \mathrm{O}_{5}}{\mathrm{ZnO}}$ & 1400 & \multirow[t]{2}{*}{$\mathrm{Li}_{2} \mathrm{SiO}_{3}$} & $\beta$-LiAISi ${ }_{2} \mathrm{O}_{6}$ \\
\hline & SP-2 & 6.0 & 10.0 & 64.0 & ftorides & 1400 & & $\beta$-LiAlSi ${ }_{2} \mathrm{O}_{6}$ \\
\hline \multirow[t]{2}{*}{2} & SP-3 & $5.2^{*}$ & 31.6 & 37.3 & ftorides & 1550 & \multirow[t]{7}{*}{ amorphous } & $\mathrm{CaF}_{2}$ \\
\hline & $\mathrm{SP}-4$ & $5.65^{*}$ & 34.15 & 40.25 & ftorides & 1600 & & $\mathrm{NaAISiO}_{4}, \mathrm{CaF}_{2}$ \\
\hline \multirow[t]{3}{*}{3} & SP-5 & 10.0 & 12.8 & 60.0 & $\begin{array}{l}\mathrm{TiO}_{2}, \mathrm{SnO}_{2}, \\
\mathrm{ZnO}, \mathrm{ZrO} 2, \\
\quad \mathrm{P}_{2} \mathrm{O}_{5}\end{array}$ & 1450 & & $\beta$-LiAISi ${ }_{2} \mathrm{O}_{6}$ \\
\hline & SP-6 & 10.0 & 11.0 & 60.0 & $\begin{array}{c}\mathrm{TiO}_{2}, \mathrm{ZnO} \\
\mathrm{P}_{2} \mathrm{O}_{5}\end{array}$ & 1450 & & $\beta$-LiAISi ${ }_{2} \mathrm{O}_{6}$ \\
\hline & SP-7 & 7.0 & 11.0 & 55.0 & $\begin{array}{c}\mathrm{TiO}_{2}, \mathrm{ZnO} \\
\mathrm{P}_{2} \mathrm{O}_{5}\end{array}$ & 1400 & & $\beta$ - $\mathrm{LiAISi}_{2} \mathrm{O}_{6}$ \\
\hline \multirow[t]{2}{*}{4} & SP-8 & 10.0 & 15.0 & 60.0 & $\underset{\mathrm{ZnO}, \mathrm{P}_{2} \mathrm{O}_{5}}{\mathrm{CeO}}$ & 1400 & & $\begin{array}{l}\mathrm{Li}_{0.6} \mathrm{Al}_{0.6} \mathrm{Si}_{2.4} \mathrm{O}_{6} \\
\quad \mathrm{Li}_{2} \mathrm{MgSiO}_{4} \\
\end{array}$ \\
\hline & SP-9 & 8.0 & 20.0 & 60.0 & $\underset{\mathrm{CeO}_{2}}{\mathrm{ZnO}, \mathrm{P}_{2} \mathrm{O}_{5}}$ & 1400 & & $\beta$-LiAISi ${ }_{2} \mathrm{O}_{6}$ \\
\hline
\end{tabular}




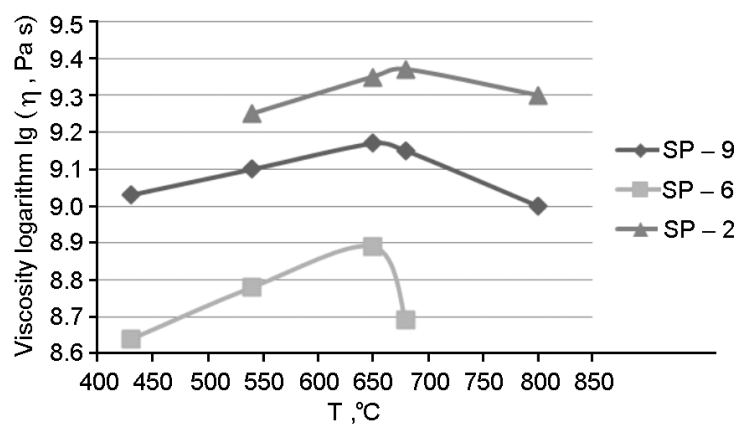

Fig. 1. Dependences of viscosity logarithm from temperature for experimental glasses.

size of $1 \mu \mathrm{m}$ in conditions of the low-temperature thermal treatment.

\subsection{Development of model glasses}

To determine the regions of existence of glasses as the base of synthesis of lithium aluminosilicate materials, $\mathrm{R}_{2} \mathrm{O}-\mathrm{RO}-\mathrm{RO}_{2}-$ $\mathrm{R}_{2} \mathrm{O}_{3}-\mathrm{LiF}-\mathrm{CaF}_{2}-\mathrm{P}_{2} \mathrm{O}_{5}-\mathrm{SiO}_{2}$ system was chosen, where $\mathrm{R}_{2} \mathrm{O}-\mathrm{Na}_{2} \mathrm{O}, \mathrm{Li}_{2} \mathrm{O}, \mathrm{K}_{2} \mathrm{O}$, RO $\mathrm{CaO}, \mathrm{MgO}, \mathrm{ZnO}, \mathrm{RO}_{2}-\mathrm{ZrO}_{2}, \mathrm{TiO}_{2}, \mathrm{R}_{2} \mathrm{O}_{3}$ - $\mathrm{Al}_{2} \mathrm{O}_{3}, \mathrm{~B}_{2} \mathrm{O}_{3}$ (Table). Depending on the amount of phase forming components and nucleators, the model glasses-ceramic materials were divided into four groups (Table). Introduction of $\mathrm{Na}_{2} \mathrm{O}$ and $\mathrm{K}_{2} \mathrm{O}$ into the glass will allow to significantly decrease the temperatures of melting and thermal treatment, and along with introduction of $\mathrm{B}_{2} \mathrm{O}_{3}$ and $\mathrm{MnO}_{2}$ to decrease their density, which is an important condition of obtaining the technologically effective lightweight glass-ceramic materials. To provide volume crystallized structure, traditional catalysts with different action mechanism, such as $\mathrm{TiO}_{2}, \mathrm{ZrO}_{2}$, $\mathrm{SnO}_{2}$ and fluorides were selected. Distinctive feature of the model glasses is that they contain $\mathrm{P}_{2} \mathrm{O}_{5}$ and $\mathrm{ZnO}$ which explains their ability to form fine the interlocked structure. At the same time, presence of $\mathrm{P}_{2} \mathrm{O}_{5}$ in the structure of the model glasses allows to decrease specimen's stress and strain that result from absorbing the energy of impact.

In the experimental system the field of the model glasses of SP series was confined in determined concentration limits and the glasses were synthesized as the base for obtaining the spodumene glass-ceramic materials (GCM). The glasses of SP series were melted in the same conditions at $1400 \div 1600^{\circ} \mathrm{C}$ in corundum crucibles with consequent cooling on the stainless steel sheet. The model glasses with different ratio and amounts of glass-forming components are divided into opacified (group 1) and transparent (group 2, 3 and 4) (Table) by the pattern of the crystalline phase occurrence after melting.

\section{Results and discussion}

\subsection{Investigation of mutual influence of} viscosity and crystallization ability of model glasses

According to the data obtained from the X-ray diffraction analysis, the model glasses of group 1 are characterized by occurrence of lithium metasilicate crystalline phase after melting. The model glasses of groups 1,3 and 4 are the $\mathrm{X}$-ray amorphous after melting (Table). The petrographical analysis of these glasses has shown that all specimens were colorless anisotropic eutectic solidified melts. Composition of the model glasses contains nonuniformities of fluctuation nature, which become the most developed near eutectic points, where formation of two phases at once is possible. This allows to make a conclusion that during thermal treatment of materials based on these glasses, the strengthened fine structure is formed by directional crystallization. Investigation of phase transformations in the experimental glasses after single-stage exposure to temperatures of $450 \div 950^{\circ} \mathrm{C}$ in the gradient furnace allowed to reveal the presence of $\beta$-spodumene crystalline phase in the amount of $60 \mathrm{vol}$ \% in all glasses of groups 1, 3 and SP-9 glass of the group 4 .

To determine the values of viscosity on the stages of nucleation and crystal growth that are optimal from the standpoint of achieving intensive fine crystallization of $\beta$-spodumene, crystallization viscosity of the glasses from different groups was investigated: SP-2, SP-6 and SP-9.

The results of the viscosity investigation (Fig. 1) have shown that distinctive feature of all experimental glasses is the abnormal increase of viscosity in the glass transition range $T_{g}-T_{f}$, which is related to the formation of nuclei and the crystal growth. Level of crystallization viscosity increase is determined by the amount of crystal phase, and grows with the increase of its amount. In the temperature interval of $650 \div 800^{\circ} \mathrm{C}$ (Fig. 1) a characteristic dependence of viscosity versus temperature is observed for the experimental glasses (decrease of viscosity upon increase of temperature). This is explained by the fact that upon temperature increase there comes a point when the rate of temperature increase begins to outrun 
the rise of viscosity which leads to a gap on viscosity curve [8].

Significant increase of crystallization viscosity $\eta=10^{9.4} \mathrm{~Pa} \cdot \mathrm{s}$ at $680^{\circ} \mathrm{C}$ for $\mathrm{SP}-2$ glass is the evidence of both intensive nucleation and crystal growth (about 30 vol. \%), which have been formed during cooling after melting of the glasses. Absence of the crystalline phase after melting for glasses SP-6 and SP-9 leads to somewhat reduced value of their viscosity $\eta=10^{8,7}$ and $10^{9,2} \mathrm{~Pa} \cdot \mathrm{s}$, respectively (Fig. 1).

According to results of the gradient thermal analysis, the high values of viscosity of SP-2 glass in vicinity of softening temperature influence on the shift of crystallization of $\beta$-spodumene to the high temperature field of $900 \div 950^{\circ} \mathrm{C}$. For SP-2 and SP-9 glasses the field of opalescence is observed, which is characteristic manifestation of the metastable phase separation for these glasses at lower temperatures of $550 \div 650^{\circ} \mathrm{C}$. Introduction of manganese and cerium oxides to SP-9 glass allows to decrease their low-temperature and high-temperature viscosity. For that reason, after the long-term heating at $850 \div 900^{\circ} \mathrm{C}$, transformation of $\beta$-eucryptite solid solution into $\beta$-spodumene occurs.

The mutual influence of viscosity and crystallization ability is observed indirectly on DTA curves. The results of DTA show that for SP-2, SP-6 and SP-9 model glasses the temperature rang of glass transition is determined by their viscosity and for the highly viscous glass SP-2 it is $(480 \div 580)^{\circ} \mathrm{C}$ (Fig. 2). For SP-6 and SP-9 glasses this range is shifted to the low-temperature field and equals $(450 \div 550)^{\circ} \mathrm{C}$.

The SP model glasses at large are characterized by DTA curves typical to the glass-ceramic materials. The high and narrow exothermic effect peaks may be evidence of formation of the fine structure with consequent volume crystallization at high temperatures. Proximity of the first exothermic effect to endothermic effect is linked with crystallization of vitreous material at high viscosity near softening temperature, which allows to conclude that crystallization of the specimen will take place without its deformation. There is always a minimum before the maximum that corresponds to irreversible crystallization process, in particular, to pre-crystallization increase of the heat capacity.

Distinct exothermic effects are observed on the thermograms of SP-2, SP-6 and SP-9 glasses in the temperature range of $650 \div 680^{\circ} \mathrm{C}$, which are related to the crystal-

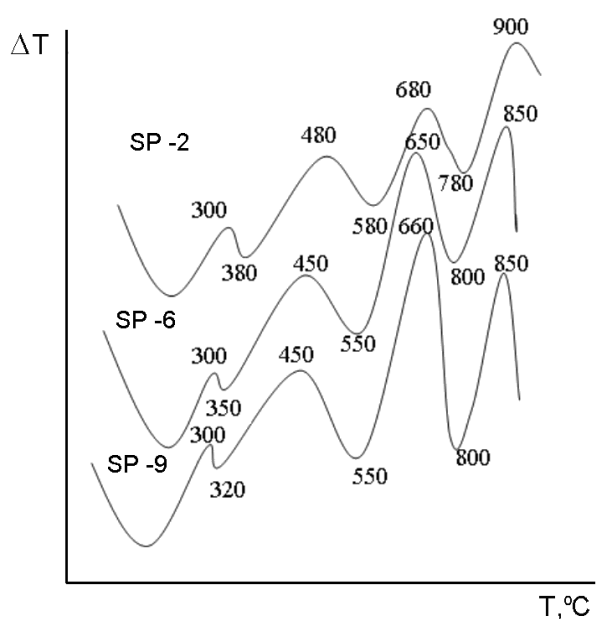

Fig. 2. Thermograms of experimental glasses.

lization of $\beta$-eucryptite in them (Fig. 2). Further thermal treatment of the glass-ceramic material at $780 \div 900^{\circ} \mathrm{C}$ leads to recrystallization of $\beta$-eucryptite metastable crystals into stable $\beta$-spodumene $\left(\mathrm{Li}_{2} \mathrm{O} \cdot \mathrm{Al}_{2} \mathrm{O}_{3} \cdot 2 \mathrm{SiO}_{2} \rightarrow \quad \mathrm{Li}_{2} \mathrm{O} \cdot \mathrm{Al}_{2} \mathrm{O}_{3} \cdot 4 \mathrm{SiO}_{2}\right)$ by vitreous $\mathrm{SiO}_{2}$ with respective increase of the crystalline phase. The largest area of endothermic effect located before exothermic effect of $\beta$-spodumene crystallization which determines its quantity belongs to SP-9 glass. The fluctuations formation with the following nucleation process at softening temperature TE allows to provide fine volume crystallization with formation of the high-strength $\beta$-spodumene phase in the amount of 60 vol. \% with the crystal size of $1 \mu \mathrm{m}$ in conditions of the low-temperature thermal treatment at viscosity of $10^{9,2} \mathrm{~Pa} \cdot \mathrm{s}$. For SP-2 glass significant increase of viscosity in the glass transition range results in shifting of $\beta$-spodumene crystallization into the high-temperature region, which can lead to strength degradation of the glass structure. Along with that, more slant exothermal effect on the thermogram of this glass which can be the evidence of enlargement of the crystalline phase already formed after melting, is an additional driver of decreasing the strength of vitreous material on its base. On the other side, in the low-viscosity conditions, prerequisites for occurrence of sufficient quantities of compositional fluctuations necessary for formation of the glass-ceramic structure of SP-6 glass are not met. 


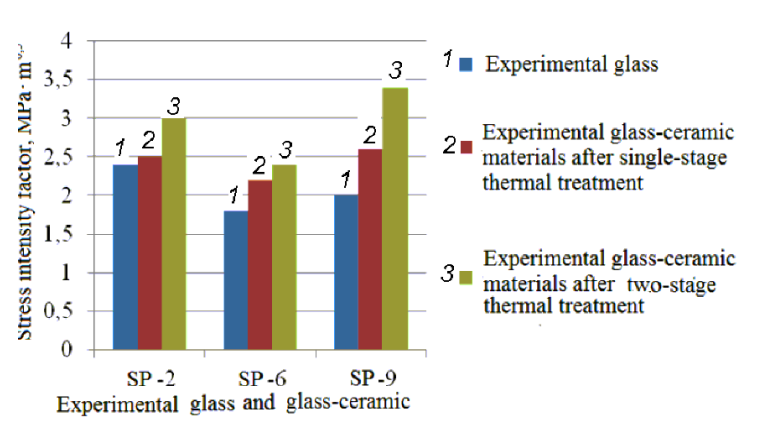

Fig. 3. Dependence of crack toughness from the type of thermal treatment.

3.2. Investigation of influence of experimental glass-ceramic materials structure on their mechanical properties

Results of investigation of mechanical characteristics of the experimental glasses and developed glass-ceramic materials after single-stage thermal treatment allowed to establish that the structure of the developed material is stronger in comparison with the initial glasses. Increase of the crack toughness parameter of the experimental material is related to the structure characteristics of the developed glass-ceramics, in particular, to the blocking of microcracks with pores and crystalline phase during crystallization.

The highest microhardness values $H=$ $5900 \mathrm{MPa}$ pertain to SP-2 glass with lithium metasilicate present after melting. After single-stage thermal treatment, due to formation of the glass-ceramic structure, the highest microhardness value of $H=7890 \mathrm{MPa}$ pertained to SP-9 experimental glass. $\beta$-eucryptite crystallization during the nucleation phase for SP-9 experimental glass and strength degradation as a result of the crystal growth for SP-2 experimental glass does not allow for sufficiently high values of stress intensity after single-stage thermal treatment.

Formation of the strengthened glass ceramic structure was realized in conditions of low-temperature two-stage thermal treatment: stage I $-530^{\circ} \mathrm{C}$, stage II $-900^{\circ} \mathrm{C}$ (glasses SP-6, SP-9); stage I $-530^{\circ} \mathrm{C}$, stage II $-950^{\circ} \mathrm{C}$ (glass SP-2). Because of the presence of $\beta$-spodumene fine crystals which are uniformly distributed in the volume of experimental glass-ceramic materials in the amount of 80 vol. \%., SP-2, SP-6 and SP-9 have the values of microhardness $H=8330 \div 9084 \mathrm{MPa}$ and crack toughness in the range of $K_{1 C}=2.8 \div 3.4$, which is an important factor in absorbing impact energy of the bullet without cracks and breakdown. These microhardness and crack toughness values are higher compared to the initial glasses and glass-ceramic materials obtained by the single-stage treatment, (Fig. 3).

According to the investigations results it has been established that SP-9 experimental glass-ceramic material obtained by the twostage low-temperature thermal treatment, is characterized by the highest values of mechanical characteristics among other experimental materials and can be used as a base in obtaining materials for personal armor protection.

\section{Conclusions}

Thus, importance of obtaining protective spodumene glass-ceramic materials for elements of personal armor protection was analyzed. Mechanism of phase formation in the materials was determined, which consists in fine volume crystallization of the glass with formation of $\beta$-eucryptite or lithium metasilicate at the viscosities of $10^{8.7 \div 9.2} \mathrm{~Pa} \cdot \mathrm{s}$ and their recrystallization into stable $\beta$-spodumene crystals in the amount of $60 \div 80$ vol. $\%$ in conditions of single- and two-stage thermal treatment. It was established that formation of the glass ceramic structure of the material with optimal composition with $\beta$-spodumene provides strength characteristics of $H==7890 \mathrm{MPa}$, $K_{1 C}=3.4 \mathrm{MPa} \cdot \mathrm{m}^{0.5}$ and allows to use them as a base in obtaining elements of personal armor protection.

\section{References}

1. P.D.Sarkisov, Directional Crystallization of Glass is the Basis of Obtaining Polyfunctional Glass-Crystalline Materials, RKhTU im. Mendeleyeva, Moscow (1997) [in Russian].

2. V.Cannillo, L.Lusvarghi, T.Manfredini et al., J.Eur. Cer. Soc., 27, 1293 (2007).

3. Ya.I.Vakhula, Bases of Technology of GlassCeramics, "Lvivska Politekhnika", Lviv (2009) [in Ukrainian].

4. L.L.Bragina, A.P.Zubekhin, Ya.I.Belyy et al., Technology of Enamels and Protective Coatings, NTU "KhPI", Kharkov, YuRGTU (NPI), Novocherkassk (2003) [in Russian].

5. B.G.Varshal, Two-phase Glasses: Structure, Properties, Application, Nauka, Leningrad (1991) [in Russian].

6. O.V.Savvova, O.V.Babich, G.N.Shadrina, Functional Materials, 21, 421 (2014).

7. Yu.A.Guloyan, Physico-Chemical Bases of Glass Technology, Transit-IKS, Vladimir (2008) [in Russian].

8. G.V.Lisachuk, M.I.Ryshchenko, L.A.Belostotskaya et al., Glass-Ceramic Coatings on Ceramics, NTU "KhPI", Kharkov (2008) [in Russian]. 